Proc. Indian Acad. Sci. (Earth Planet. Sci.), Vol. 95, No. 2, July 1986, pp. 285-292.

(C) Printed in India.

\title{
Origin and depositional environment of the china clay deposits of south Kerala
}

\author{
K SOMAN and TERRY MACHADO \\ Centre for Earth Science Studies, Trivandrum 695010, India \\ MS received 8 October 1985; revised 1 March 1986
}

\begin{abstract}
Results of petrographic, mineralogic and granulometric studies of the sedimentary china clay deposits of Trivandrum district in south Kerala are discussed in terms of their origin and depositional environment. While mineralogic data indicate a khondalitic source for the kaolins as against the hitherto postulated leptynitic source, petrographic evidences suggest that most of the kaolinite were transported from the weathering crust and deposited. Granulometric data and SEM scanning of sand grains from the clays indicate their deposition in a fluvial/low energy littoral environment under conditions of subaqueous agitation.
\end{abstract}

Keywords. China clay; Warkalli beds; kaolinite; khondalite; leptynite; pelagic suspension; fluvial environment.

\section{Introduction}

The upper Tertiary sedimentary sequence in Trivandrum district, south Kerala belonging to the Warkalli beds of Mio-Pliocene age contains a column of kaolin clays over the current bedded variegated sandstones, grits, lignite beds etc (Foote 1883; Menon 1966). The kaolin clay beds attain a maximum thickness of about $4.5 \mathrm{~m}$ at Thonnakkal in Trivandrum district and the adjoining areas and prove to be of refractory quality raw material (Soman 1984). In some of the clay mines at Thonnakkal (figure 1) more than one bed of kaolin is observed, and the clay bed in most cases is covered by a laterite cover with a maximum thickness of upto 8-10 m (figure 2). Based on the presence of heavy minerals like sillimanite, ilmenite, anatase and graphite in the clays and sandstones at the Karruchal section, south east of Trivandrum and in the sediments of the Warkalli beds, Menon (1966) suggested that the clays were derived from leptynites. However, sillimanite, ilmenite, anatase and graphite are rare in the leptynites compared to their content in the khondalite sensu stricto. The purpose of this paper is to present the petrographic, mineralogic and size analysis data on the sedimentary kaolin clays of Trivandrum district and to discuss their origin and depositional environment.

\section{Petrography and mineralogy}

Investigations of the clay occurrences in south Kerala show that the kaolin incorporates almost entirely the fine grained kaolinite (above $95 \%$ ) with occasional columnar and sheaf-like aggregates (figure 3a) having $N_{p}=1.564$. Aggregates of kaolinite resembling vermicular forms of upto $0.2 \times 0.004 \mathrm{~mm}$ size (figure $3 \mathrm{~b}$ ) and ovalshaped kaolinite within fine kaolinite matrix are also seen under the microscope. 




Figure 1. Location map of the china clay mines at Thonnakkal, south Kerala: 1. EnglishIndia clay mine, 2 . Industrial enterprise clay mine, 3. Standard clay mine.

Preponderance of kaolinite in the clays is substantiated by DTA and x-ray data (figure 4). SEM photomicrographs and $x$-ray data showing higher first order spacings

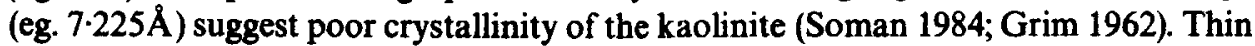
and polished section studies show the presence of quartz; gibbsite (pseudomorphous after kaolinite), allophane, goethite, hematite, sillimanite, feldspars and graphite in insignificant quantities. Rutile, sphene and zircon are accessory minerals. While the proximity of the kaolin deposits to the khondalite terrain of south Kerala and occurrence of sillimanite and graphite as key minerals would indicate a khondalitic 


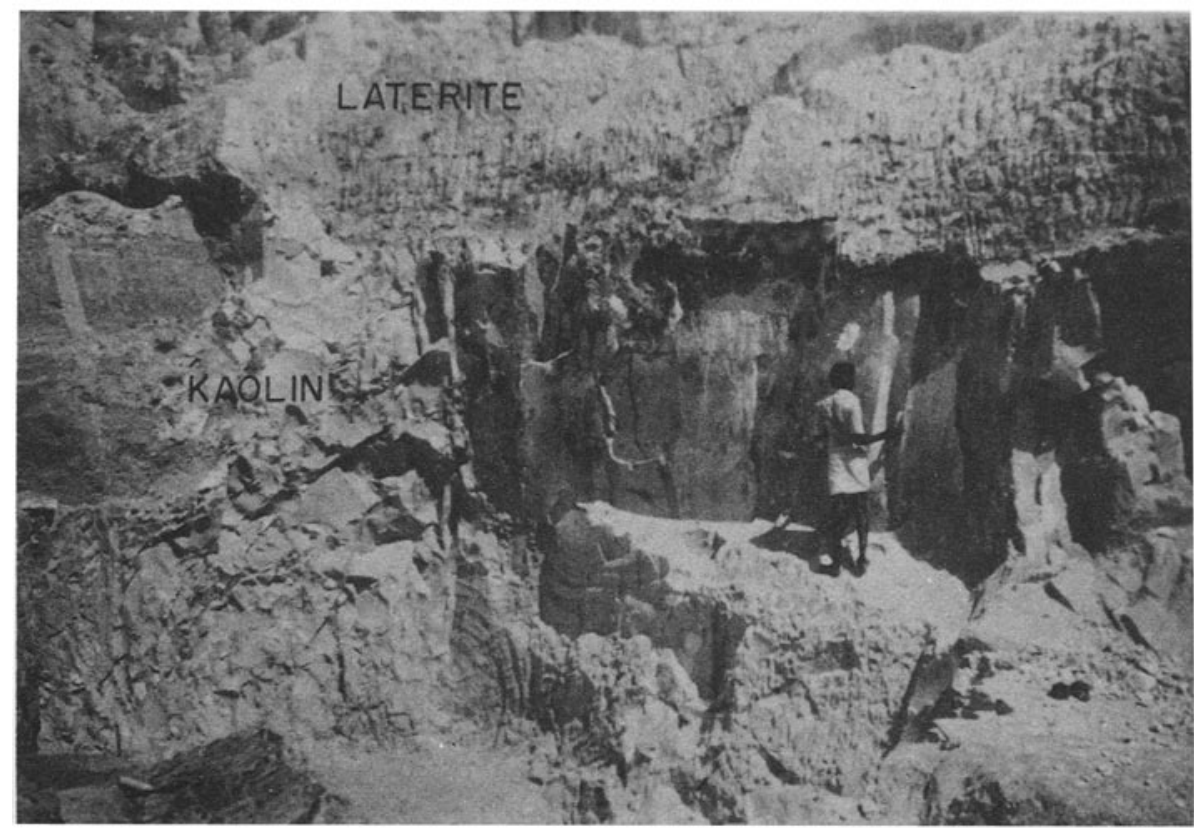

Figure 2. Field photograph showing thick laterite cover over kaolins. English-India Clay mine, Thonnakkal.

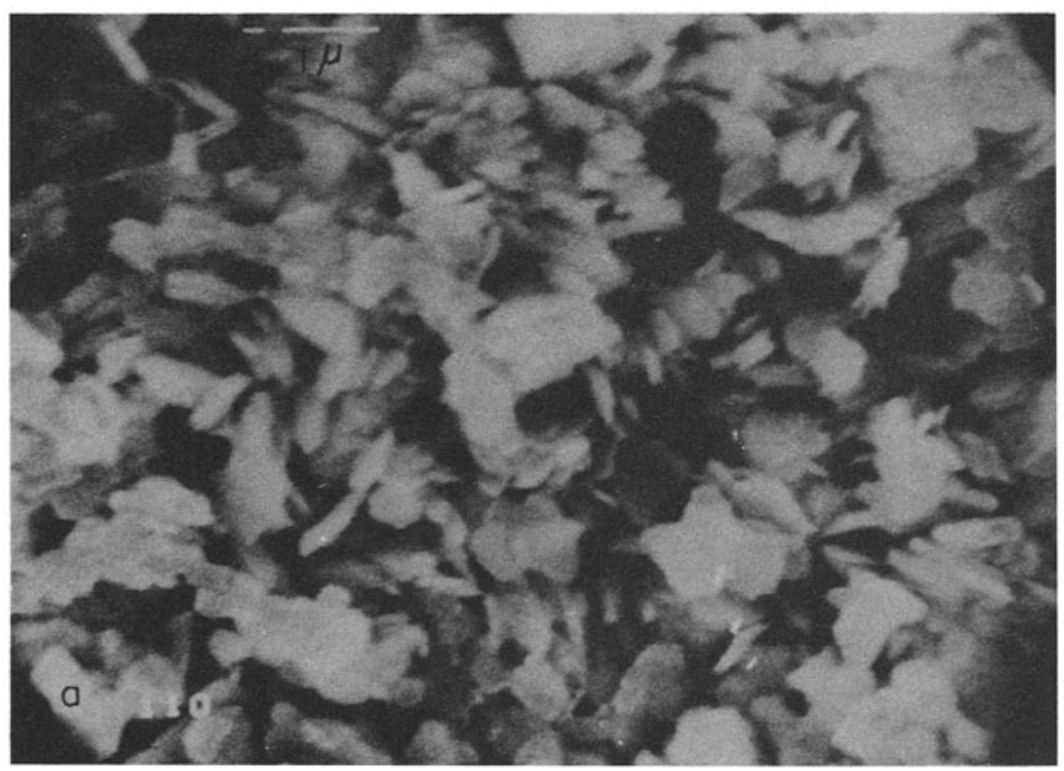

Figure 3. (a).

source for the clays, the presence of oval-shaped kaolinite aggregates suggest that kaolinite itself was transported from the weathering crust developed on the khondalites during the Warkalli sedimentation cycle. Poor crystallinity of kaolinite in the 


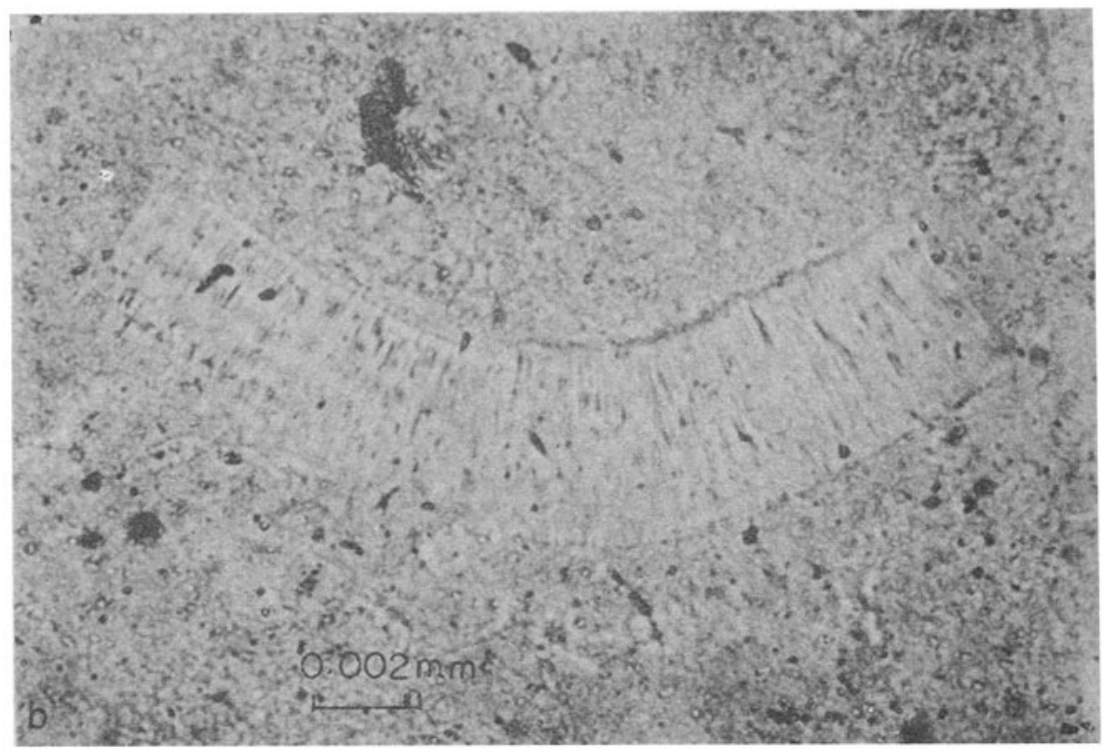

Figure 3. (a) SEM photomicrograph of sheaf-like aggregates of kaolinite. Photograph taken in an ISI-60A SEM with $15 \mathrm{kV}$ accelerating potential and gold-coating of the samples.

(b) Photomicrograph of kaolinite showing vermicular forms. Plane polarized light.
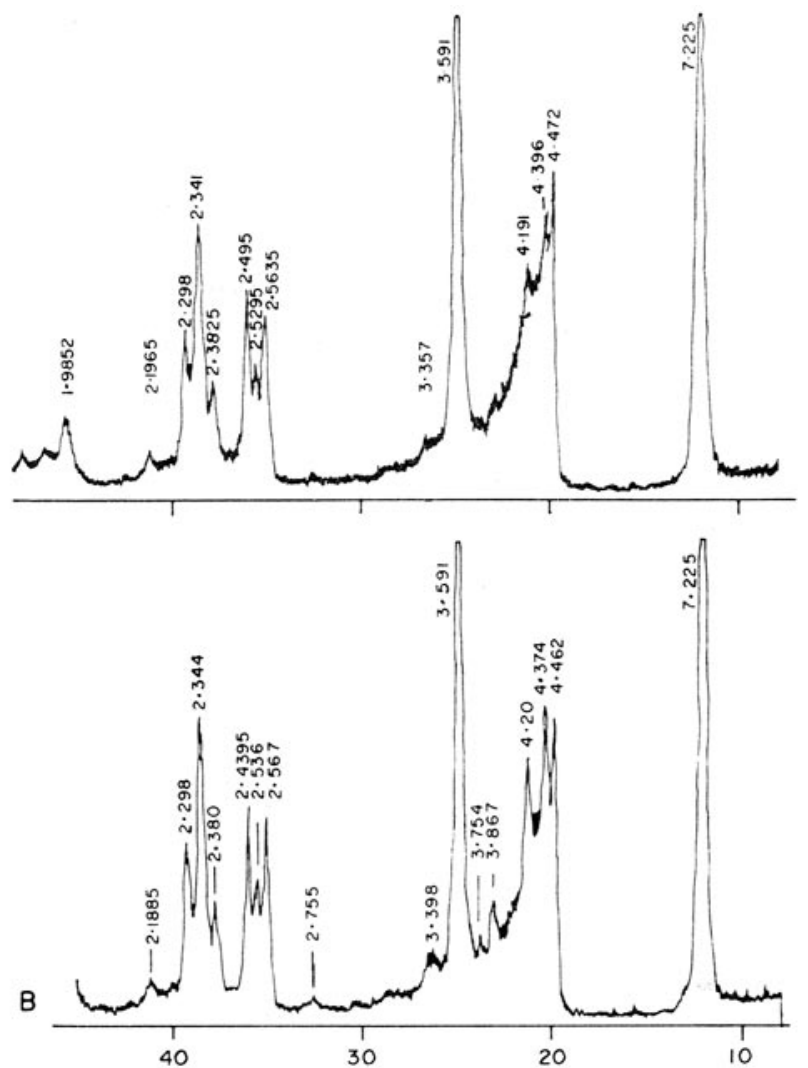

Figure 4(a). X-ray diffractograms of kaolin clays from (A) Industrial enterprise mine and (B) standard clay mine, Thonnakkal. Instrumental set-up: $\mathrm{CuK}_{\propto}, 40 \mathrm{kV}$ accelerating potential, mA-20 with graphite monochromator, CPS-1000. 


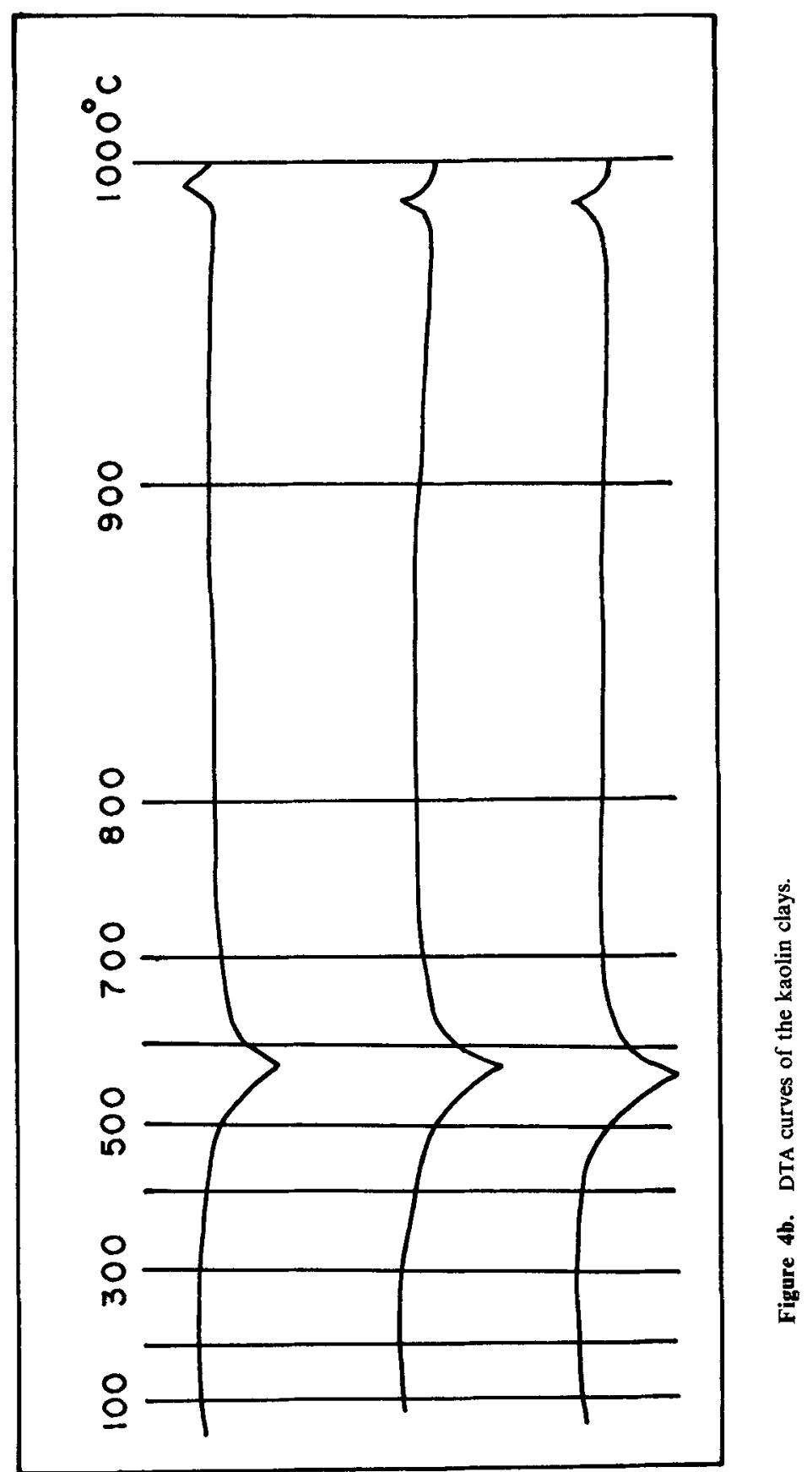


sedimentary clays compared to its well crystalline nature in the primary clays from the present-day weathering crust (Soman and Slukin 1985) also support the view that kaolinite was transported.

\section{Size parameters}

Size analysis of 13 clay samples from three vertical profiles belonging to three clay mines, located laterally apart, from Thonnakkal area was carried out according to the method recommended by Carver (1971). Plots of first and fiftieth percentile values of the size analysis in a C-M diagram (Passega 1957, 1977; Vandernberghe 1975) mostly fall around the bottom left corner of pelagic suspension (figure 5). This would indicate deposition in still waters with or without gentle agitation. Passega (1977) showed that such a situation can result in shallow waters also when a turbidity current becomes gradually dissipated and left only with clay particles. SEM examination of sand grains from a clay sample shows the presence of $V$ shaped impact pits in them (figure 6) which implies a subaqueous agitation in the sedimentation environments (Margolis and Kennet 1971). The density and abundance of the presently observed V-shaped impact

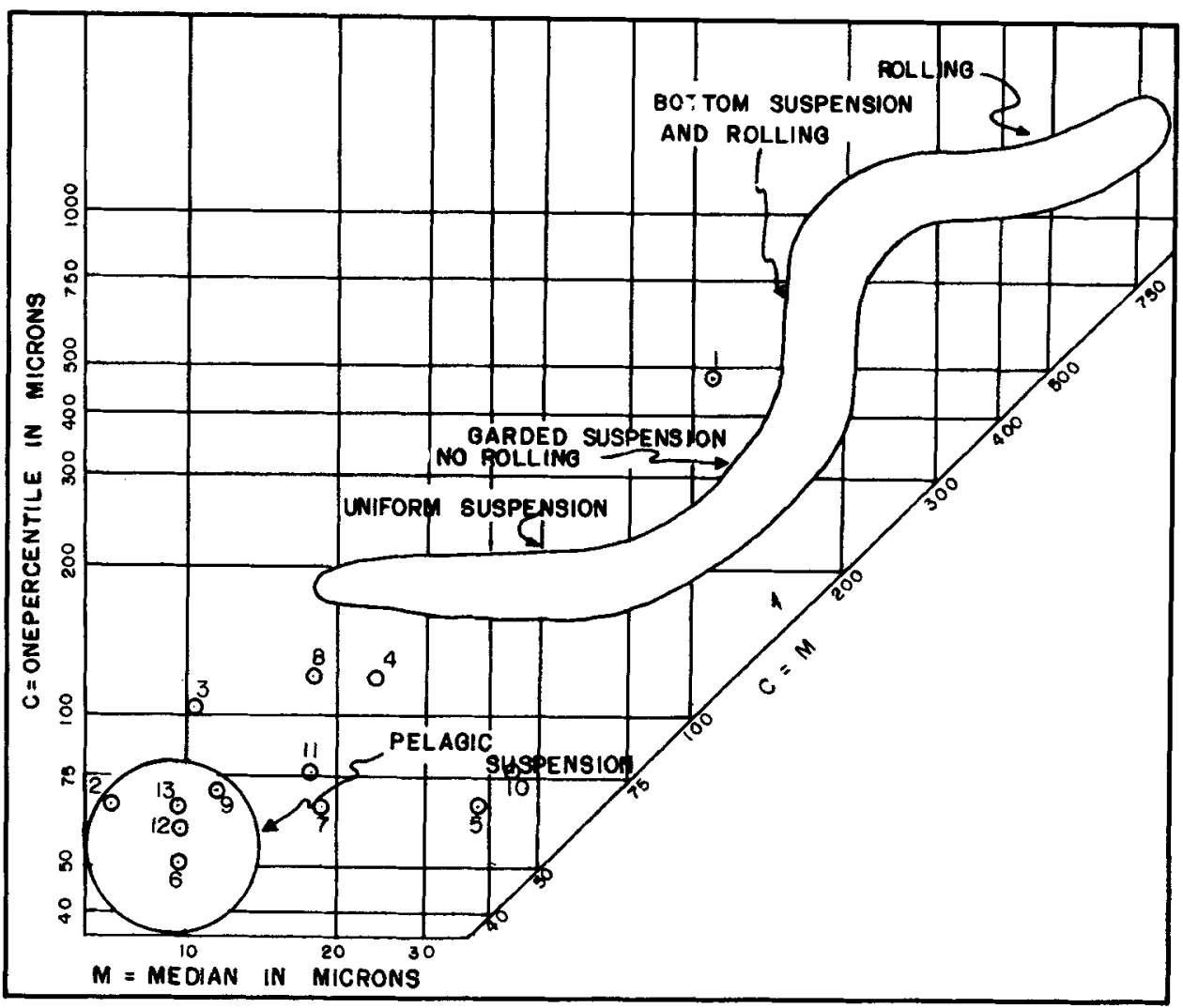

rigure 5. Plots of size analysis values in a C-M diagram (after Passega 1977). 


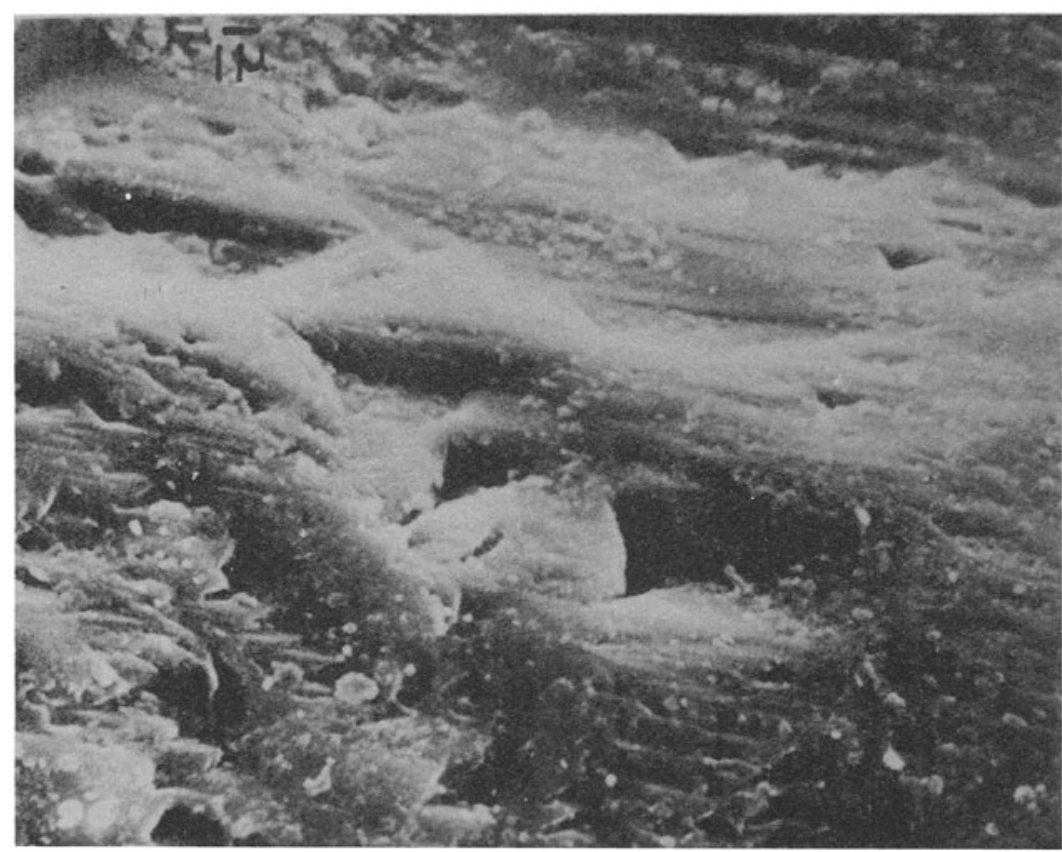

Figure 6. SEM photomicrograph of sand grain from kaolins showing V-shaped impact pits.

pits correspond to typical fluvial/low energy littoral environment (Carter 1984). The presence of current-bedded clastic sediments above and below the clay beds in south Kerala also indicates the existence of shallow water environment with high concentration of suspended sediments during Warkalli sedimentation cycle.

\section{Conclusion}

The available data suggest that the source material of the kaolin deposits of south Kerala originated from the weathering crust on the khondalite-migmatite complex during Mio-Pliocene times and these were deposited in a fluvial/low energy littoral environment under conditions of subaqueous agitation. This is compatible with the suggestion of Raha et al (1983) that the Warkalli group of sediments could possibly have developed as different facies components in a coastal environment. The presence of oval-shaped kaolinite aggregates and poor crystallinity of the kaolinite further suggest that kaolinite itself was transported, while the presence of graphite indicate that the transportation distance of the material could not have been long.

\section{References}

Carter J M L 1984 Sedimentology 31722

Carver R E 1971 Proceedings in sedimentary petrology (New York: Wiley-Interscience and John Wiley), p. 72 Foote R B 1883 Rec. Geol. Surv. India 1625 
Grim R E 1962 Applied clay mineralogy. International Series in the Earth \& Planetary Sciences (New York: McGraw-Hill) p. 12

Margolis S V and Kennet J P 1971 Bull. Geol. Soc. Am. 823398

Menon K K 1966 Bull. Geol. Soc. India 378

Passega R 1957 Bull. Am. Assoc. Petr. Geol. 411956

Passega R 1977 Sedimentology 24723

Raha P K, Sinha Roy S and Rajendran C P 1983 J Geol. Soc. India 24339

Soman K 1984 Geology and mineral resources of Trivandrum, Kerala State, India. Unpubl. Ph. D thesis, Friendship Univ., Moscow

Soman K and Slukin A D 1985 Proc. Int. Seminar on Laterite, Tokyo (preprint)

Vandernberghe N 1975 Sedimentology 22618 